\section{Overcoming Dormancy and Enhancing Germination of Sphaeralcea munroana Seeds}

\author{
Olga A. Kildisheva \\ Center for Forest Nursery and Seedling Research, College of Natural \\ Resources, University of Idaho, P.O. Box 441133, Moscow, ID 83843
}

R. Kasten Dumroese

USDA Forest Service Rocky Mountain Research Station, 1221 South Main

Street, Moscow, ID 83843

\author{
Anthony S. Davis ${ }^{1}$ \\ Center for Forest Nursery and Seedling Research, College of Natural \\ Resources, University of Idaho, P.O. Box 441133, Moscow, ID 83843
}

Additional index words. Munro's globemallow, Malvaceae, germination, imbibition, water gap, gibberellic acid

\begin{abstract}
The results of a series of experiments involving a variety of dormancy-breaking treatments indicate that Munro's globemallow [Sphaeralcea munroana (Douglas) Spach] seeds are physically dormant, possess a cap-like structure in the occlusion of the water gap, which inhibits imbibition, and can be artificially dislodged through boiling water scarification. The highest germination capacity $(93 \%)$ was achieved by mechanical scarification of previously stored seeds. Exogenous application of a gibberellin solution and cold stratification failed to enhance germination compared with scarification alone, indicating an absence of additional dormancy types. These results should improve the usefulness of this drought-tolerant perennial for landscaping and restoration given its effectiveness in soil stabilization, tolerance to a variety of soil types, extreme temperatures, and ecological importance.
\end{abstract}

Munro's globemallow [Sphaeralcea munroana (Douglas) Spach] (Malvaceae), a herbaceous perennial endemic to the Great Basin of western North America, is an important candidate for use in horticulture and restoration. This species is able to tolerate drought, extreme temperatures, and establish on a variety of soil types. It serves as an important host for native pollinators, provides soil stabilization, and is a source of food for myriad mammals (Beale and Smith, 1970; Pendery and Rumbaugh, 1986; Rumbaugh et al., 1993). Currently, the lack of successful in and ex situ germination resulting from seed

Received for publication 5 June 2011. Accepted for publication 24 Oct. 2011.

Funding for this research was provided by the Idaho Transportation Department, the Great Basin Native Plant Selection and Increase Project, the University of Idaho Seed Grant Program, and the University of Idaho Center for Nursery and Seedling Research.

We thank Timothy R. Johnson for statistical support and Nalin Suranjith Gama-Arachchige for assistance in electron microscopy. We extend our thanks to Sabry Elias, Nancy Shaw, Matthew M. Aghai, Robert F. Keefe, Emily C. Overton, Matt Fisk, and Erin Denney who provided technical support.

This article is a portion of a thesis submitted by Olga A. Kildisheva in fulfilling a degree requirement.

${ }^{1}$ To whom reprint requests should be addressed; e-mail asdavis@uidaho.edu. dormancy limits its use in restoration. Few sources explore the dormancy mechanisms and methods that induce germination in Sphaeralcea spp. (Page et al., 1966; Roth et al., 1987).

Vleeshouwers et al. (1995) describe seed dormancy as a state "the degree of which defines what conditions should be met to make the seed germinate." These conditions are characterized based on the mechanisms that prevent germination. Physically dormant seeds have a palisade layer of lignified cells that prevents water imbibition (Corner, 1951; Vazquez-Yanes and Perez-Garcia, 1976). Although a number of species in the Sphaeralcea genus have been observed to benefit from scarification, the cause of dormancy has not been examined directly (Page et al., 1966; Roth et al., 1987; Sabo et al., 1979; Smith and Kratsch, 2009). In these species, imbibition (critical for germination) is regulated by a water gap structure located within the seedcoat. The water gap can become permeable after exposure to temperature flux, drying, or scarification, thus allowing imbibition into an otherwise impermeable seed (Baskin, 2003; Baskin and Baskin, 1998; Baskin et al., 2000).

Ex situ, chemical and mechanical scarification has been used to improve germination of physically dormant seeds (Baskin and Baskin, 1998; Hoffman et al., 1989; Page et al., 1966; Roth et al., 1987). For example, Page et al. (1966) reported an up to $40 \%$ increase in germination of $S$. grossulariifolia after submergence in sulfuric acid, a substantial improvement compared with the control $(0 \%)$. Similarly, submergence of Sphaeralcea seeds in $18 \mathrm{M}$ sulfuric acid for $10 \mathrm{~min}$ improved germination of $S$. coccinea and two accessions of $S$. grossulariifolia $(77 \%, 69 \%$, and $62 \%)$ relative to the controls $(5 \%, 14 \%$, and $32 \%$ ), but failed to do so for $S$. munroana (8\%) compared with the control (2\%) (Roth et al., 1987). Organic solvents have also been used to promote germination of physically dormant seeds. Page et al. (1966) reported $67 \%$ germination of treated $S$. grossulariifolia seeds after a 4-h submergence in diethyl dioxide vs. $0 \%$ germination of untreated seeds. Roth et al. (1987) found a 3-h submergence of $S$. coccinea, $S$. munroana, and two accessions of $S$. grossulariifolia in diethyl dioxide to significantly enhance germination $(36 \%, 53 \%, 89 \%$, and $68 \%)$ compared with the control $(5 \%, 2 \%, 14 \%$, and $32 \%$ ). Despite the effectiveness of chemical scarification, chemicals can be hazardous, difficult to obtain, and present serious health risks (Mallinckrodt Baker, 2008a, 2008b).

Mechanical scarification has also been reported to boost germination rates of physically dormant seeds of Malvaceae species. The International Seed Testing Association recommends scarification (pierce, chip, or file off seedcoat) for Althaea hybrids (Malvaceae) (ISTA, 2011). In addition, Baskin and Baskin (1997) observed $100 \%$ germination after abrasion of Iliamna corei (Malvaceae) seeds.

Despite evidence for the presence of physical dormancy, reported germination of S. munroana has failed to exceed $53 \%$, even when dormancy was presumably broken (Roth et al., 1987; Smith and Kratsch, 2009). Thus, it is unclear whether these seeds possess additional dormancy types. Physiological dormancy, characterized by the presence of chemical inhibitors that prevent embryonic growth, is commonly found in cold desert herbaceous perennials and can be relieved by stratification (Baskin and Baskin, 1998). In addition, gibberellic acid $\left(\mathrm{GA}_{3}\right)$ has been successful in alleviating the chemical constraints that prevent radical emergence and increasing embryonic growth in a number of physically dormant species (Bewley, 1997; Hilhorst, 1995; Koornneef et al., 2002; Leubner-Metzger, 2003).

Although less common, the coupling of physical and physiological dormancy (i.e., combined dormancy) requires both types to be broken before germination can occur (Baskin and Baskin, 1998; Emery, 1987). Dunn (2011) reports increased germination of Sphaeralcea ambigua and S. coccinea (45\% and $85 \%$ ) compared with the control $(18 \%$ and $5 \%)$ after a 30 -d stratification of scarified seeds. Similarly, Smith and Kratsch (2009) report that pairing mechanical scarification (nicking of the seedcoat) with a 6-week stratification at $4{ }^{\circ} \mathrm{C}$ resulted in higher germination of the bulked seeds of $S$. grossulariifolia, S. parvifolia, and $S$. munroana than either treatment alone, suggesting that seeds of $S$. munroana may exhibit combined dormancy. 
The process of seed imbibition and the site of water entry are critical to our comprehension of the germination dynamics and treatment effects. To address these questions, three experiments were initiated. The first experiment 1) compared water uptake of nontreated, mechanically scarified, and boiling water scarified seeds; and 2) identified the primary site of water uptake. The second experiment investigated the germination response of fresh $S$. munroana seeds to mechanical scarification with a sharp blade, 6-week stratification, and their combination. The third experiment evaluated the germination behavior of stored seeds after mechanical scarification, submergence duration in gibberellic acid solution or deionized (DI) water, and several combinations of these treatments.

\section{Materials and Methods}

Three experiments were conducted at the University of Idaho Center for Forest Nursery and Seedling Research (Moscow, ID). Before each experiment, seeds were sterilized with chlorine bleach $(0.5 \% \mathrm{NaOCl}$ solution $)$ for 15 min and double-rinsed with DI water. For the first two experiments, seeds were collected in Aug. 2010 near Payette, ID (lat. 4352' 49.6" $\mathrm{N}$, long. $\left.116^{\circ} 47^{\prime} 01.8^{\prime \prime} \mathrm{W}\right)$ and air-dried at $21 \pm 1{ }^{\circ} \mathrm{C}$ for $7 \mathrm{~d}$ before the initiation of the trials. Expt. 3 used seeds obtained from native stands throughout the Wasatch Mountains of northern Utah (Great Basin Seeds LLC, Ephraim, UT) and stored at $1.5 \pm 0.5^{\circ} \mathrm{C}$ for 6 months before use.

Expt. 1: imbibition and microscopy. This experiment identified the primary site of water uptake and compared imbibition of seeds after exposure to three treatments: 1) control (dry, unaltered seeds); 2) mechanical scarification with a sharp blade opposite the chalaza; and 3) boiling water scarification achieved by a 10 -s submergence in $100{ }^{\circ} \mathrm{C}$ water. Each treatment contained 10 15-seed replicates. All seeds were placed onto DImoistened blotter (Steel Blue germination blotter; Anchor Paper Co., St. Paul, MN) inside petri dishes (Fisher Scientific Co., Pittsburgh, PA) and kept on a laboratory bench for the duration of the experiment. Seeds in each replicate were initially weighed to the nearest $0.1 \mathrm{mg}$ and reweighed (after being blotted to reduce the presence of free water) at $1-\mathrm{h}$ intervals for $10 \mathrm{~h}$ and once at the end of the 24-h observation period (GamaArachchige et al., 2010). Mass increase, expressed as a mean percentage gain on a dry mass basis, was calculated. An additional sample of control and boiling water-scarified seeds that did not undergo the imbibition treatment were sent to the Electron Microscopy Center at the University of Kentucky, Lexington, KY, and scanned with a Hitachi (S-3200; Hitachi High Technologies America Inc., Pleasanton, CA) scanning electron microscope (acceleration voltage of $5.0 \mathrm{kV}$ ) (Gama-Arachchige et al., 2010). The chalazal region and the dislodged chalazal cap were observed and photomicrographed.
Expt. 2: scarification and stratification. This experiment assessed the presence of physical, physiological, and combined dormancy by comparing germination behavior after exposure to a 1) control (dry, unaltered seeds); 2) mechanical scarification (previously described); 3) 6-week stratification at $4.6 \pm 0.02{ }^{\circ} \mathrm{C}$ on moistened blotter inside sealed petri dishes; and 4) combined scarification + stratification treatment. The blotters were remoistened with $5 \mathrm{~mL}$ of DI water every $3 \mathrm{~d}$ to avoid a potential reduction in dormancy break resulting from substrate desiccation, which can result in lower oxygen availability (Flemion, 1931; Stokes, 1965). Seeds in the combination treatment were scarified first (Smith and Kratsch, 2009). All treatments consisted of five 50-seed replicates.

Expt. 3: scarification, gibberellic acid, and water. This experiment was conducted to evaluate the effects of gibberellin on germination. Seeds were subject to eight treatments: 1) control (dry, unaltered seeds); a 2) mechanical scarification (previously described); 3) 24-h and 4) 48-h soak in 100 ppm $\mathrm{GA}_{3}$ solution; 5) scarification $+24 \mathrm{~h}$ and 6) $48 \mathrm{~h}$ soak in DI water; 7) scarification + $24 \mathrm{~h}$; and 8) 48-h soak in 100 ppm $\mathrm{GA}_{3}$ solution. $\mathrm{GA}_{3}$ solution consisted of $90 \%$ gibberellin $\mathrm{A}_{3}$ basis (Sigma-Aldrich Co., St. Louis, MO) and DI water. All treatments had five 50-seed replicates. Despite the $95.5 \%$ purity reported by the vendor for the seeds used in this experiment, we further cleaned seeds in an air column separator (Model B; E.L. Erickson, Brookings, SD) to reduce the presence of empty seeds. The satisfactory level of cleaning was determined by X-ray image analysis (MX-20 Radiography System; Faxitron X-ray Corp., Lincolnshire, IL); a substantial amount of seeds, mostly light brown in color, were removed.

Germination conditions. Seeds were placed onto germination blotter (soaked with DI water) inside randomly arranged, sealed, plastic petri dishes, kept at $24{ }^{\circ} \mathrm{C}$ day $/ 17^{\circ} \mathrm{C}$ night temperature within a germination chamber (Hoffman Manufacturing Inc., Albany, OR). Germination (defined by 5 -mm radical length or greater) was monitored daily for $21 \mathrm{~d}$ (Page et al., 1966).

Statistical analysis. All experiments followed a randomized complete block design. Specific treatment differences were explored with a one-way analysis of variance and Tukey's honestly significant difference ( $\alpha=$ 0.05) (Version 9.2; SAS Institute Inc., Cary, NC). In Expt. 1, the dependent variable was seed mass increase (\%) on a dry mass basis.

Although germination capacity (i.e., cumulative germination percentage at the end of the testing period) is conventionally used to assess seed performance, other factors (i.e., germination rate and uniformity) are important (Ching, 1959; Thomson and ElKassaby, 1993). Combining multiple parameters into a single variable in an attempt to better describe germination performance has failed to provide a holistic representation of germination (Czabator, 1962). To avoid this in our analysis, we fit daily germination data to one of two mathematical models, the parameters of which give a detailed description of seed behavior. This approach also alleviated the need for data transformation.

In Expt. 2, a three-parameter model was used [Eq. (1)] in which $G(t)$ is the cumulative germination percentage at time $(t)$ expressed in days (d), $G_{c}$ is germination capacity or the germination asymptote at the end of the testing period (\%), $G C_{50}$ is the time in days required to reach $50 \%$ germination, and $\mathrm{G}_{d}$ is the germination rate $(\% /$ day $)$. As a result of differences in germination behavior in Expt. 3 , an alternative model that better fit this set of data was used [Eq. (2)] in which $\mathrm{G}_{d}$ was replaced with $\mathrm{G}_{l}$, defined as the time in days to first germination. All remaining parameters were identical to those described previously. Parameters $\left(\mathrm{G}_{c}, \mathrm{GC}_{50}, \mathrm{G}_{d}, \mathrm{G}_{l}\right)$ for each replication were generated by curve-fitting. Expected mean squares, components of variance, and $R^{2}$ values were estimated for all parameters. The dependent variables assessed were $\mathrm{G}_{c}, \mathrm{GC}_{50}, \mathrm{G}_{d}, \mathrm{G}_{l}$.

$$
\begin{gathered}
\boldsymbol{G}(\boldsymbol{t})=\frac{\boldsymbol{G}_{\boldsymbol{c}}}{1+\boldsymbol{e} \frac{\boldsymbol{G C _ { 0 0 } ^ { - t }}}{\boldsymbol{G}_{d}}} \\
\boldsymbol{G}(t)=\boldsymbol{G}_{\boldsymbol{c}}\left[1-\boldsymbol{e}^{-e^{G C_{50}\left(t-G_{l}\right)}}\right]
\end{gathered}
$$

\section{Results}

Expt. 1: imbibition and microscopy. Mechanical and boiling water scarification resulted in significant increases $(P<0.0001$ and $P=0.0347)$ in water uptake compared with the control (Fig. 1). The measurements for three of the 10 replicates were systematic outliers, did not alter the statistical relationship between treatments, and were excluded from this analysis. Mechanically scarified seeds exhibited greater $(P<0.0001)$ mass gain compared with the boiling water scarification at the end of the 24-h observation period (Fig. 1). The photomicrographic evaluation revealed that the chalazal region of $S$. munroana seeds possesses a water gap that in dormant seeds is covered by a cap-like structure made up of maternal tissues and palisade cells (Fig. 2A-B). Boiling water scarification caused a contiguous crack to form around the chalazal region, eventually allowing for the dislodgement of the cap and subsequent seed imbibition (Fig. 2B-D).

Expt. 2: scarification and stratification. Of the parameters fit to Eq. [1], $\mathrm{G}_{c}$ was significantly different among all treatments, whereas $\mathrm{GC}_{50}$ and $\mathrm{G}_{d}$ were not $(P<0.0001$, $P=0.3530$, and $P=0.4526$ ) (Table 1). Most of the variation in $\mathrm{G}_{c}\left(R^{2}=0.77\right)$ was explained by the differences in treatment. Germination was enhanced $(P=0.0030$ and $P=0.0002)$ with scarification $(35 \%)$ and the combined scarification and stratification (44\%) (Fig. 3). Combining both treatments failed $(P=0.5191)$ to improve $\mathrm{G}_{c}$ of fresh seeds when compared with scarification alone. 


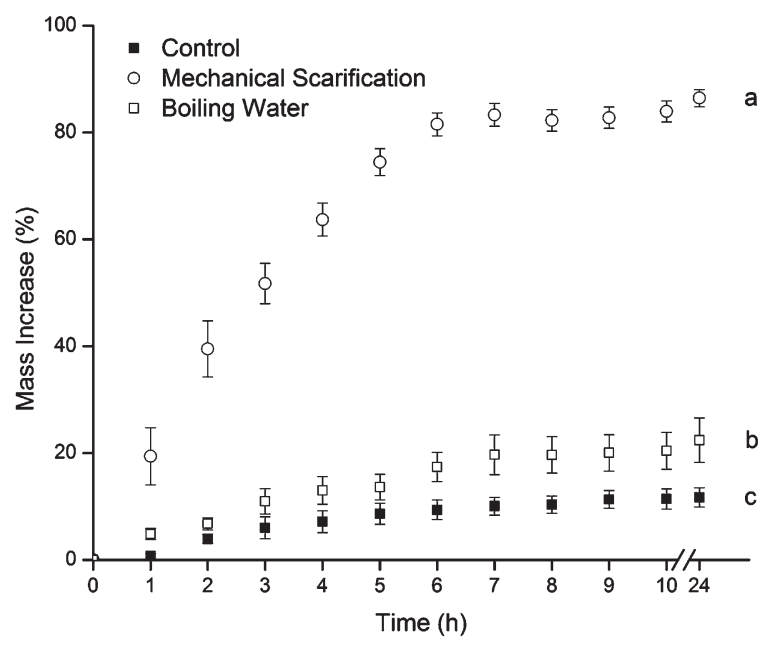

Fig. 1. Mass increase percentage on a dry mass basis after 1) control (dry, unaltered seeds); 2) mechanica scarification; and 3) boiling water scarification of Sphaeralcea munroana seeds during a 24-h incubation at $21 \pm 1{ }^{\circ} \mathrm{C}$. Data represents the mean $( \pm \mathrm{SE})$ of seven replicates. Different letters indicate significant differences $(P \leq 0.05)$ at the end of the 24-h period.
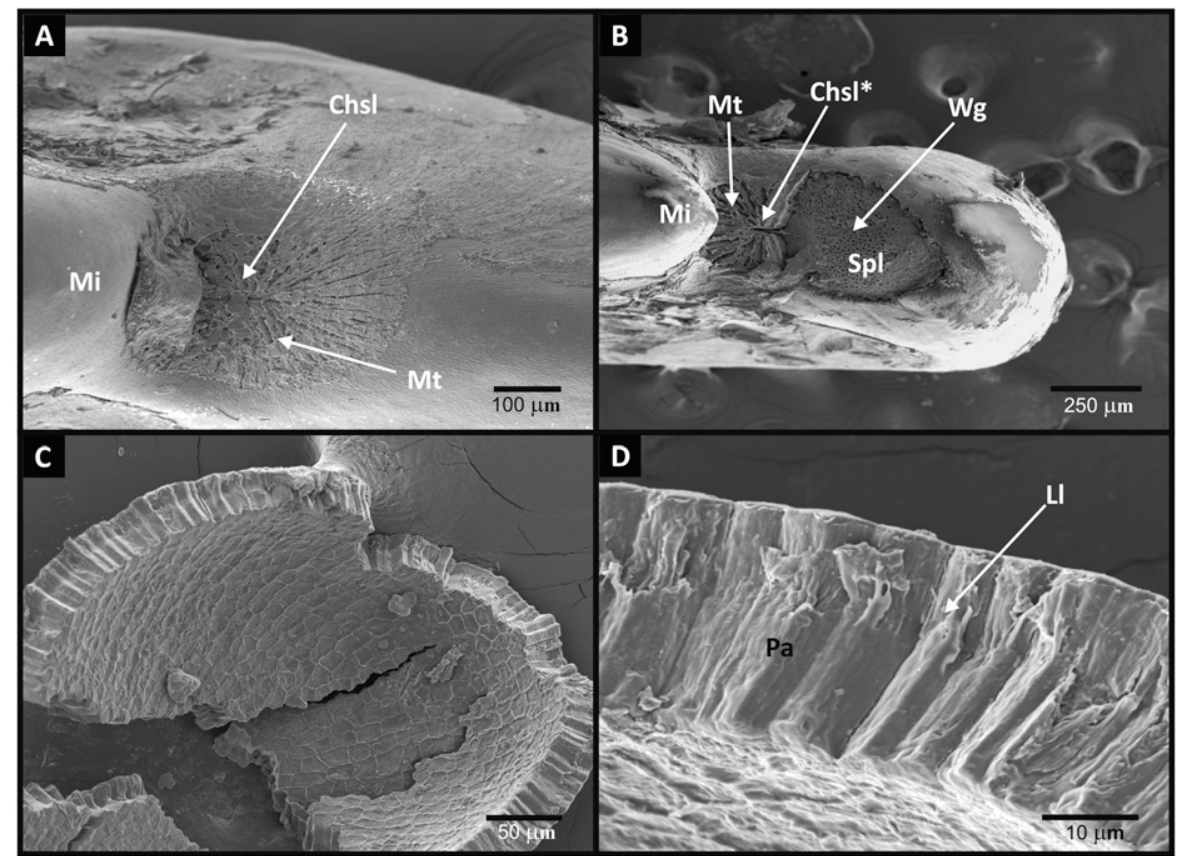

Fig. 2. Scanning electron photomicrographs of Sphaeralcea munroana seeds; (A) top view of the chalazal region of a dormant seed showing the chalazal slit; (B) formation of water gap after dormancy break by boiling water scarification; (C) the underside of the dislodged cap-like blister covering the water gap; (D) palisade cells of the cap-like structure. $\mathrm{Chsl}=$ chalazal slit; $\mathrm{Chsl}{ }^{*}=$ remaining part of the chalazal slit after dormancy break; $\mathrm{Ll}=$ light line; $\mathrm{Mi}=$ micropyle; $\mathrm{Mt}=$ maternal tissue; $\mathrm{Pa}=$ palisade; $\mathrm{Spl}=$ subpalisade cells; $\mathrm{Wg}$ = water gap.

Table 1. Germination parameter estimates for freshly collected seeds of S. munroana after four treatments.

\begin{tabular}{lccc}
\hline Treatment & $\mathrm{G}_{c}(\%)$ & $\mathrm{GC}_{50}(\mathrm{~d})$ & $\mathrm{G}_{d}(\% / \mathrm{d})$ \\
\hline Control & $8.35 \pm 2.2 \mathrm{a}^{\mathrm{z}}$ & $8.06 \pm 4.5 \mathrm{a}$ & $4.09 \pm 2.5 \mathrm{a}$ \\
Scarification & $35.29 \pm 6.3 \mathrm{~b}$ & $6.99 \pm 0.6 \mathrm{a}$ & $2.36 \pm 0.5 \mathrm{a}$ \\
Stratification & $7.21 \pm 2.1 \mathrm{a}$ & $3.34 \pm 1.3 \mathrm{a}$ & $1.15 \pm 0.6 \mathrm{a}$ \\
Scarification + stratification & $44.12 \pm 5.6 \mathrm{~b}$ & $2.87 \pm 0.4 \mathrm{a}$ & $1.77 \pm 0.2 \mathrm{a}$ \\
$P$ & 0.0001 & 0.3530 & 0.4526 \\
\hline
\end{tabular}

${ }^{\mathrm{z}}$ Different letters indicate significant differences among treatments $(P \leq 0.05)$.

Expt. 3: scarification, gibberellic acid, and water. All of the parameters fit to Eq. [2] $\left(\mathrm{G}_{c}, \mathrm{GC}_{50}\right.$, and $\left.\mathrm{G}_{l}\right)$ were different among treatments $(P<0.0001, P=0.0005$, and $P=$
0.0386) (Table 2). Most of the variation in $\mathrm{G}_{c}$ $\left(R^{2}=0.93\right)$ was explained by differences in treatment. The correlation was not as strong for $\mathrm{GC}_{50}\left(R^{2}=0.53\right)$ and $\mathrm{G}_{l}\left(R^{2}=0.35\right)$ parameters. Results confirm that $S$. munroana seeds are physically dormant with scarified seeds exhibiting a higher $(P<0.0001)$ germination compared with non-scarified seeds. Exogenous addition of $\mathrm{GA}_{3}$ did not promote germination of the non-scarified seeds. Scarification, scarification + water $(24 \mathrm{~h})$, and scarification $+\mathrm{GA}_{3}(24 \mathrm{~h})$ yielded the greatest $\mathrm{G}_{c}(87 \%, 93 \%$, and $88 \%)$ at the end of $21 \mathrm{~d}$ (Fig. 4). The $\mathrm{G}_{c}$ was higher $(P=0.0328)$ for scarification + water $(24 \mathrm{~h})$ than for scarification + water $(48 \mathrm{~h})$-treated seeds. However, a similar relationship did not exist $(P=0.9669)$ between scarified $+\mathrm{GA}_{3}$ treatments. $\mathrm{GC}_{50}$ was significantly lower for $\mathrm{GA}_{3}$ $(48 \mathrm{~h})$, scarified, and scarified $+\mathrm{GA}_{3}(24$ and $48 \mathrm{~h})$ treatments compared with the control, suggesting that seeds in these treatments germinated more rapidly. Seeds in the scarification $+\mathrm{GA}_{3}(24 \mathrm{~h})$ treatment began germination later $(P=0.0497)$ than their cohorts in the scarification + water $(48 \mathrm{~h})$ treatment.

\section{Discussion}

Our results suggest that seedcoat impermeability in Munro's globemallow is indicative of physical dormancy. The occurrence of the water gap structure in the chalazal region of the seed, responsible for water uptake after dormancy break, is analogous to other Malvaceae species (Christiansen and Moore, 1959; Egley and Paul, 1981, 1982; Egley et al., 1986). Permeability can be achieved by mechanical and boiling water scarification. Presumably a result of the separation of the palisade and subpalisade layers of cells, boiling water scarification caused the detachment of the cap-like structure in the occlusion of the water gap, allowing imbibition to occur (Serrato-Valenti et al., 1992). Temperature fluctuations during an extended period of time may generate similar results in situ. Because seed mass increased to $86 \%$ after mechanical and to $22 \%$ after boiling water scarification, it appears that the tested boiling water scarification duration caused only partial water gap opening.

The observation that mechanical scarification amplified $\mathrm{G}_{c}$ coincides with Baskin and Baskin (1997) who reported optimal germination of mechanically scarified seeds of $I$. corei. We found a lack of evidence for the presence of additional dormancy (i.e., physiological and combined) with both stratification of fresh seeds and soaking of stored seeds in $\mathrm{GA}_{3}$ solution failing to boost $\mathrm{G}_{c}$ compared with scarification alone.

These findings are contrary to the reported germination improvements in seeds of Sphaeralcea spp. after the combination of scarification and stratification (Dunn, 2011; Smith and Kratsch, 2009). Thus, it is possible that the perceived benefit of stratification is not exposure to cool temperatures, but rather that the seeds, partially permeable after scarification, gradually imbibe water throughout the duration of the cold, moist treatment, finally reaching an optimum moisture content for germination.

For previously stored seeds, the addition of $\mathrm{GA}_{3}(24 \mathrm{~h})$ to scarified seeds amplified $\mathrm{G}_{c}$ 


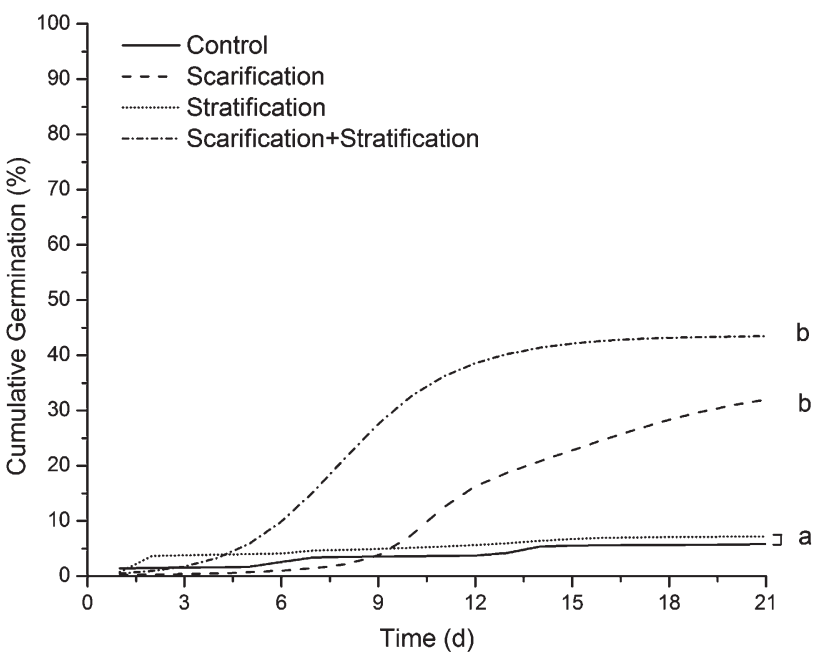

Fig. 3. Cumulative germination percentage of Sphaeralcea munroana seeds subject to four seed treatments: 1) control (dry, unaltered seeds); 2) mechanical scarification; 3) 6-week stratification at $4.6 \pm 0.02{ }^{\circ} \mathrm{C}$; and 4) combined scarification + stratification treatments. Seeds in all treatments were placed onto DI water-soaked blotters and kept at $24{ }^{\circ} \mathrm{C}$ day/17 ${ }^{\circ} \mathrm{C}$ night temperature within a germination chamber for $21 \mathrm{~d}$. Each line represents the mean response of five replicates. Different letters indicate significant differences $(P \leq 0.05)$ between treatments. DI $=$ deionized.

Table 2. Germination parameter estimates for stored seeds of Sphaeralcea munroana after eight treatments.

\begin{tabular}{lccc}
\hline Treatment & $\mathrm{G}_{c}(\%)$ & $\mathrm{GC}_{50}(\mathrm{~d})$ & $\mathrm{G}_{l}(\mathrm{~d})$ \\
\hline Control & $15.9 \pm 4.5 \mathrm{c}^{\mathrm{z}}$ & $2.7 \pm 0.5 \mathrm{a}$ & $0.1 \pm 0.1 \mathrm{ab}$ \\
Scarification & $87.1 \pm 3.8 \mathrm{ab}$ & $0.7 \pm 0.2 \mathrm{~b}$ & $0.3 \pm 0.1 \mathrm{ab}$ \\
$\mathrm{GA}_{3}(24 \mathrm{~h})$ & $15.9 \pm 2.3 \mathrm{c}$ & $1.7 \pm 0.6 \mathrm{ab}$ & $0.4 \pm 0.2 \mathrm{ab}$ \\
$\mathrm{GA}_{3}(48 \mathrm{~h})$ & $15.1 \pm 2.4 \mathrm{c}$ & $0.9 \pm 0.3 \mathrm{~b}$ & $0.2 \pm 0.2 \mathrm{ab}$ \\
Scarification $+\mathrm{GA}_{3}(24 \mathrm{~h})$ & $88.1 \pm 3.9 \mathrm{ab}$ & $0.6 \pm 0.1 \mathrm{~b}$ & $0.6 \pm 0.1 \mathrm{~b}$ \\
Scarification $+\mathrm{GA}_{3}(48 \mathrm{~h})$ & $81.7 \pm 1.8 \mathrm{ab}$ & $0.6 \pm 0.1 \mathrm{~b}$ & $0.4 \pm 0.2 \mathrm{ab}$ \\
Scarification + water $(24 \mathrm{~h})$ & $93.4 \pm 2.9 \mathrm{a}$ & $1.5 \pm 0.3 \mathrm{ab}$ & $0.5 \pm 0.1 \mathrm{ab}$ \\
Scarification + water $(48 \mathrm{~h})$ & $71.9 \pm 9.3 \mathrm{~b}$ & $1.8 \pm 0.4 \mathrm{ab}$ & $0.0 \pm 0.0 \mathrm{a}$ \\
$P$ & 0.0001 & 0.0005 & 0.0386 \\
\hline
\end{tabular}

${ }^{\mathrm{z}}$ Different letters indicate significant differences among treatments $(P \leq 0.05)$.

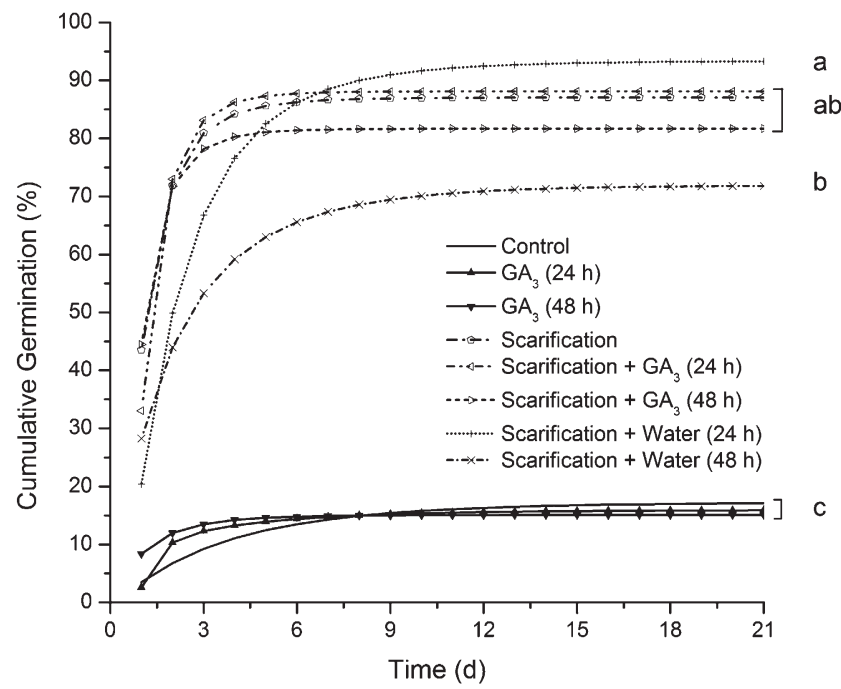

Fig. 4. Cumulative germination percentage of Sphaeralcea munroana seeds after exposure to eight treatments: 1) control (dry, unaltered seeds); a 2) mechanical scarification; 3) 24-h and 4) 48-h soak in 100 ppm gibberellin $\left(\mathrm{GA}_{3}\right)$ solution; 5) scarification + 24-h and 6) 48-h soak in deionized (DI) water; 7) scarification $+24 \mathrm{~h}$; and 8) 48-h soak in 100 ppm GA 3 solution. Each line represents the mean response of five replicates. Different letters indicate significant differences $(P \leq 0.05)$.

over the control, but was not different from water $(24 \mathrm{~h})$, and was likely a result of soaking itself. It is possible that a higher concentration of $\mathrm{GA}_{3}$ was needed to influence germination behavior. For example, in a study comparing the effects of 500 and
1000 ppm of $\mathrm{GA}_{3}$, only the 1000 ppm solution enhanced germination of Harrisia fragrans (Dehgan and Pérez, 2005). Considering, however, that a $\mathrm{G}_{c}$ of $93 \%$ was achieved by the scarification + water, gibberellins are unlikely to play an important role in alleviating dormancy of $S$. munroana.

It is important to note that the germination of $S$. munroana reported for Expt. 3 (93\%) was much higher than previously observed (51\% for $S$. munroana and $88 \%$ for other Sphaeralcea spp.) (Roth et al., 1987; Smith and Kratsch, 2009). It is unclear which factors were responsible for the high cumulative germination in our study. Although all experiments were conducted independently and were not subject to between-experiment comparisons, anecdotally the control and mechanical scarification treatments in Expt 3 (conducted with seeds stored at $1.5 \pm 0.5^{\circ} \mathrm{C}$ for 6 months) exhibited higher germination $(16 \%$ and $87 \%)$ than those in Expt. 2 (8\% and $35 \%$ ). This suggests that storage conditions may play an important part in dormancy break; the role of storage temperature, duration, and conditions (i.e., wet, dry) must be further evaluated.

Finally, collection timing is closely coupled with seed maturity and moisture content, which have a strong effect on dormancy strength and germination (Dornbos et al., 1989; Michael et al., 2007). For example, Michael et al. (2007) report that seeds of Malva parviflora (Malvaceae) decreased in moisture content and germination capacity with seed development until reaching complete physiological maturity. Germination declines were associated with the development of physiological dormancy and the enhancement of physical dormancy as a result of declining seed moisture content (Michael et al., 2007). Thus, high temperature and low moisture content during the growing season may contribute to the degree of dormancy development in seeds of $S$. munroana and could offer an explanation into the reported differences in seed requirements for dormancy release.

\section{Conclusion}

Sphaeralcea munroana seeds exhibit strong physical dormancy as a result of the impermeability of the seedcoat and the presence of a cap-like structure in the occlusion of the water gap, which inhibits water imbibition and prevents germination. Seedcoat scarification is essential for germination of both stored and fresh seeds, after which seeds may further benefit from submergence in water. We achieved the highest germination capacity (93\%) ever reported for S. munroana by mechanically scarifying seeds previously stored for 6 months under cold, dry conditions. Thus, an effective method for breaking dormancy in seeds of S. munroana should include scarification of stored seeds. Furthermore, seed collecting, cleaning, and storage practices may play an important, yet relatively unexplored, role in increasing germination. 


\section{Literature Cited}

Baskin, C.C. 2003. Breaking physical dormancy in seeds-Focussing on the lens. New Phytol. 158:229-232.

Baskin, C.C. and J.M. Baskin. 1998. Seeds: Ecology, biogeography and evolution of dormancy and germination. Academic Press, San Diego, CA.

Baskin, J.M. and C.C. Baskin. 1997. Methods of breaking seed dormancy in endangered species Iliamna corei (Sherff) (Malvaceae), with special attention to heating. Nat. Areas J. 17:313-323.

Baskin, J.M., C.C. Baskin, and X. Li. 2000. Taxonomy, anatomy and evolution of physical dormancy in seeds. Plant Species Biol. 15:139152.

Beale, D.M. and A.D. Smith. 1970. Forage use, water consumption, and productivity of pronghorn antelope in western Utah. J. Wildl. Manage. 34:570-582.

Bewley, J.D. 1997. Seed germination and dormancy. Plant Cell 9:1055-1066.

Ching, T.M. 1959. Activation of germination in Douglas-fir seed by hydrogen peroxide. Plant Physiol. 34:557-563.

Christiansen, M.N. and R.P. Moore. 1959. Seed coat structural differences that influence water uptake and seed quality in hard seed cotton. Agron. J. 27:156-160.

Corner, E.J.H. 1951. The leguminous seed. Phytomorphology 1:117-150.

Czabator, F.J. 1962. Germination value: An index combining speed and completeness of pine seed germination. For. Sci. 8:386-396.

Dehgan, B. and H.E. Pérez. 2005. Germination of Caribbean applecactus. Native Plants J. 6:91-96.

Dornbos D.L., Jr., R.E. Mullen, and R.M. Shibles. 1989. Drought stress effects during seed fill on soybean seed germination and vigor. Crop Sci. 29:476-480.

Dunn, B. 2011. Improved germination of two Sphaeralcea A. St.-Hil. (Malvaceae) species with scarification plus stratification treatments. Native Plants J. 12:13-16.

Egley, G.H. and R.N. Paul. 1981. Morphological observations on the early imbibition of water by Sida spinosa (Malvaceae) seeds. Amer. J. Bot. 68:1056-1065.

Egley, G.H. and R.N. Paul. 1982. Development, structure and function of the subpalisade cells in water impermeable Sida spinosa seeds. Amer. J. Bot. 69:1402-1409.

Egley, G.H., R.N. Paul, and A.R. Lax. 1986. Seed coat imposed dormancy-histochemistry of the region responsible for controlling the onset of water entry into Sida spinosa seeds. Physiol. Plant. 67:320-327.

Emery, D.E. 1987. Seed propagation of native California plants. Santa Barbara Botanic Garden, Santa Barbara, CA.

Flemion, F. 1931. After-ripening, germination, and vitality of seeds of Sorbus aucuparia L. Cont. Boyce Thompson Inst. 3:413-439.

Gama-Arachchige, N.S., J.M. Baskin, R.L. Geneve, and C.C. Baskin. 2010. Identification and characterization of the water gap in physically dormant seeds of Geraniaceae, with special reference to Geranium carolinianum. Ann. Bot. (Lond.) 105:977-990.

Hilhorst, H.W.M. 1995. A critical update on seed dormancy. 1. Primary dormancy. Seed Sci. Res. 5:61-73.

Hoffman, M.T., R.M. Cowling, C. Douie, and S.M. Pierce. 1989. Seed predation and germination of Acacia eriolob in the Kuiseb River Valley, Namib Desert. S. African J. Bot. 55:103-106.

ISTA. 2011. International rules for seed testing. International Seed Testing Assoc., Bassersdorf, Switzerland

Koornneef, M., L. Bentsink, and H. Hilhorst. 2002. Seed dormancy and germination. Curr. Opin. Plant Biol. 5:33-36.

Leubner-Metzger, G. 2003. Functions and regulation of beta-1,3-glucanases during seed germination, dormancy release and after-ripening. Seed Sci. Res. 13:17-34.

Mallinckrodt Baker. 2008a. 1,4-Dioxane, MSDS No. D7552. 19 May 2008. <http://www.jtbaker. com $/ \mathrm{msds} /$ englishhtml/d7552.htm>.

Mallinckrodt Baker. 2008b. Sulfuric Acid, MSDS No. S8236. 21 Apr. 2008. <http://www.jtbaker. com/msds/englishhtml/s8236.htm>.
Michael, P.J., K.J. Steadman, and J.A. Plummer. 2007. Seed development in Malva parviflora: Onset of germinability, dormancy and desiccation tolerance. Aust. J. Exp. Agr. 47:683688.

Page, R.J., D.L. Goodwin, and N.E. West. 1966. Germination requirements of scarlet globemallow. J. Range Mgt. 19:145-146.

Pendery, B.M. and M.D. Rumbaugh. 1986. Globemallows: Forbs for Utah rangelands. Utah Sci. 47:41-45.

Roth, T.E., J.L. Holechek, and M.Y. Hussain. 1987. Germination response of 3 globemallow species to chemical treatment. J. Range Mgt. 40:173175.

Rumbaugh, M.D., H.F. Mayland, B.M. Pendery, and G.E. Shewmaker. 1993. Utalization of globemallow (Sphaeralcea) taxa by sheep. J. Range Mgt. 46:103-109.

Sabo, D.G., G.U. Johnson, W.C. Martin, and E.F. Aldon. 1979. Germination requirements of 19 species of arid land plants. U.S. Dept. Agr. For. Serv. Res. Paper RM-210, Fort Collins, CO.

Serrato-Valenti, G., L. Cornara, S. Lotito, and L. Quagliotti. 1992. Seed coat structure and histochemistry of Abelmoschus esculentus. Chalazal region and water entry. Ann. Bot. (Lond.) 69:313-321.

Smith, A. and H. Kratsch. 2009. Seed Propagation of Sphaeralcea (Globemallow). HortScience 44:1139-1140.

Stokes, P. 1965. Temperature and seed dormancy, p. 746-803. In: Ruhland, W. (ed.). Encyclopedia of plant physiology. Springer-Verlag, New York, NY.

Thomson, A.J. and Y.A. El-Kassaby. 1993. Interpretation of seed-germination parameters. New For. 7:123-132.

Vazquez-Yanes, C. and B. Perez-Garcia. 1976. Notas sobre la morfologia y la anatomia de la testa de las semillas de Ochroma lagopus Sw. Turrialba 26:310-311.

Vleeshouwers, L.M., H.J. Bouwmeester, and C.M. Karssen. 1995. Redefining seed dormancy: An attempt to integrate physiology and ecology. J. Ecol. 83:1031-1037. 